\title{
RESUME
}

\section{Operating System Structure}

\author{
ANTONIO ALFAREZ HIDAYAT \\ 195120004 \\ FAKULTAS KOMPUTER \\ antonio.students@umitra.ac.id
}

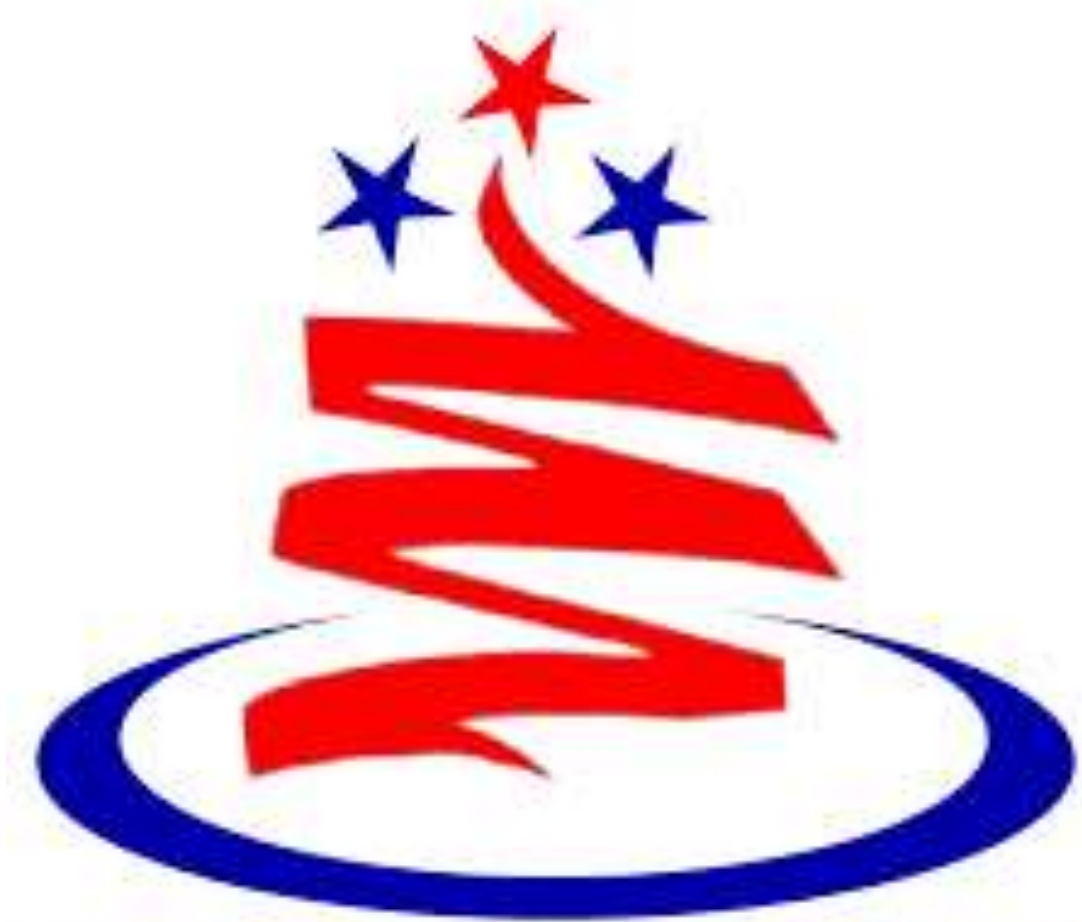

UnIVERSITAS MITRA INDONESIA

DAFTAR ISI 


\section{A. Komponen Sistem Operasi}

B. Layanan Sistem Operasi

C. Sistem Call

D.Sistem Program

E.Struktur Sistem Operasi

F.Mesin Virtual.

Isi Resume :

Sistem operasi terdiri dari beberapa komponen, antara lain manajemen proses, manajemen memori utama, manajemen file, manajemen sistem I/O, manajemen 
penyimpan sekunder, system jaringan, system proteksi dan system command interpreter. Proses adalah program yang sedang dieksekusi.

\section{A. Komponen system informasi :}

Pada umumnya sebuah sistem operasi modern akan terdiri dari komponen sebagai berikut:

- Manajemen Proses.

- Manajemen Memori Utama.

- Manajemen Sistem Berkas.

- Manajemen Sistem M/K.

- Manajemen Penyimpanan Sekunder.

- Proteksi dan Keamanan.

\section{B. Layanan dalam Sistem Operasi}

\section{Pembuatan program}

Dalam pembuatan program, programmer pasti membutuhkan yang namanya debugger ketika program itu terjadi bug. Sistem operasi mempermudah dan membantu dalam mengakses proses debugger dan editor tersebut yang sudah berada di dalam program yang berbentuk utilitas.

\section{Eksekusi program}

Sistem operasi menangai semua task untuk kepentingan pengguna. Task diantaranya berupa instruksi data harus di muatkan ke dalam memori, perangkat 
I/O harus di inisialisasi termasuk juga file harus diinisialisasi, dan sumber daya lain harus di sipakan.

\section{Pengaksesan perangkat $\mathrm{I} / \mathrm{O}$}

Perangkat di dalam I/O terdapat instruksinya sendiri atau signal control untuk operasi. Layanan yang diberika oleh sistem operasi yaitu menjaga detailnya sehingga pemrogram dapat menganggapnya sebgai operasi pembacaan dan penulisan yang sederhana.

\section{Pengaksesan terkendali terhadap berkas}

Sebelumnya telah dikatakan bahwa perangkat menjaga detailnya. Pengakasesan terkendali di sini maksudnya adalah format file yang terdapat di dalam media penyimpanan. lebih lanjut lagi sistem operasi emnyediakan mekanisme proteksi untuk mengontrol akses ke file.

\section{Deteksi dan memberi tanggapan terhadap kesalahan}

Terjadi error atau pun kesalahan dalam komputer bekerja merupakan hal yang sering terjadi. misalnya memori error, overflow aritmetik, kesalahan perangkat. dll. Semua kesalahan yang terjadi itu sistem operasi harus membuat respons yang dapat menghilangkan eroor tersebut dengan dampak sedikit terhadap aplikasi yang berjalan.

\section{Akunting (Pencatatan)}

Dari layanan yang diberikan sudah terlihat bahwa akunting yang berarti mencatat. Sistem operasi mencatat semua statistik pemakain bermacam-macam sumber daya dan memonitor parameter kinerja seperti waktu respons.

\section{C.System Calls}


Komputer digunakan untuk melakukan suatu proses yang dikehendaki user. Oleh karena itu harus ada suatu bentuk komunikasi antara user dan hardware. Komunikasi itu terjadi dalam bentuk system calls. SO melalui shell-nya akan menangkap perintah dari user yang kemudian akan dikomunikasikan melalui system calls. Disinilah peran SO sebagai jembatan komunikasi antara user dan hardware itu terjadi. System calls itu sendiri umumnya ditulis dalam bahasa C dan $\mathrm{C}++$.

Mengenai shell, shell itu sendiri secara umum adalah layer yang berfungsi sebagai interface antara user dan inti dalam sistem operasi (kernel). Melalui shell, user dapat memberi perintah-perintah yang akan dikirim ke sistem operasi, sehingga shell ini merupakan layer yang menerima interaksi dari user secara langsung. Shell dalam SO secara umum dibagi menjadi 2, Command Line(CLI) dan Graphical(GUI). Jadi dengan kata lain, system calls berperan sebagai interface dalam layanan-layanan yang disediakan oleh sistem operasi.

\section{D.Sistem Program}

System program menyediakan lingkungan yang nyaman untuk pengembangan dan eksekusi program. Kebanyakan user melihat system operasi yang didefinisikan oleh system program dan bukan system call sebenarnya. System program adalah masalah yang relatif kompleks, namun dapat dibagi menjadi beberapa kategori, antara lain:

a. Manipulasi File. Meliputi: membuat, menghapus, mengcopy, rename, print, dump, list pada file dan direktori.

b. Status Informasi. Meliputi: tanggal, waktu (jam, menit, detik), penggunaan memori atau disk space, banyaknya user.

c. Modifikasi File. Ada beberapa editor yang sanggup digunakan sebagai sarana untuk menulis atau memodifikasi file yang tersimpan dalam disk atau tape.

d. Bahasa Pemrograman yang mendukung. Meliputi: Compiler, assambler, dan interpreter untuk beberapa bahasa pemrograman (seperti: Fortran, Cobol, 
Pascal, Basic, C, dan LISP).

e. Pemanggilan dan Eksekusi Program. Pada saat program dicompile, maka harus dipanggil ke memori untuk dieksekusi. Suatu sistem biasanya memiliki absolute loader, melokasikan loader, linkage editor, dan overlay loader. Juga dibutuhkan debugging sistem untuk bahasa tingkat tinggi.

f. Komunikasi. Sebagai mekanisme untuk membuat hubungan virtual antar proses, user, dan sistem komputer yang berbeda.

g. Program-program aplikasi. Sistem operasi harus menyokong programprogram yang berguna untuk menyelesaikan permasalahan secara umum, atau membentuk operasi-operasi secara umum, seperti kompiler, pemformat teks, paket plot, sistem basis data, spreadsheet, paket analisis statistik, dan games.

Sistem operasi menyediakan layanan untuk programmer sehingga dapat melakukan pemrograman dengan mudah yaitu :

a. Eksekusi Program. Sistem harus dapat memanggil program ke memori dan menjalankannya. Program tersebut harus dapat mengakhiri eksekusinya dalam bentuk normal atau abnormal (indikasi error).

b. Operasi-operasi I/O. Pada saat running program kemungkinan dibutuhkan I/O, mungkin berupa file atau peralatan I/O. Agar efisien dan aman, maka user tidak boleh mengontrol I/O secara langsung, pengontrolan dilakukan oleh sistem operasi.

c. Manipulasi sistem file. Kapabilitas program untuk membaca, menulis, membuat dan menghapus file.

d. Komunikasi. Komunikasi dibutuhkan jika beberapa proses yang sedang dieksekusi saling tukar-menukar informasi. Penukaran informasi dapat dilakukan oleh beberapa proses dalam satu komputer atau dalam komputer yang berbeda melalui sistem jaringan. Komunikasi dilakukan dengan cara berbagi memori (shared memory) atau dengan cara pengiriman pesan (message passing).

e. Mendeteksi kesalahan. Sistem harus menjamin kebenaran dalam komputasi dengan melakukan pendeteksian error pada CPU dan memori, perangkat I/O atau pada user program. Beberapa fungsi tambahan yang ada tidak digunakan untuk membantu user, tetapi lebih digunakan untuk menjamin operasi sistem yang efisien, yaitu : 
- Mengalokasikan sumber daya (resource). Sistem harus dapat mengalokasikan resource untuk banyak user atau banyak job yang dijalanan dalam waktu yang sama.

- Akutansi. Sistem membuat catatan daftar berapa resource yang digunakan user dan resource apa saja yang digunakan untuk menghitung secara statistik akumulasi penggunaan resource.

- Proteksi. Sistem operasi harus menjamin bahwa semua akses ke resource terkontrol dengan baik.

\section{E.Struktur Sistem Operasi}

Secara umum, Sistem Operasi adalah software pada lapisan pertama yang ditempatkan pada memori komputer pada saat komputer dinyalakan. Sedangkan software-software lainnya dijalankan setelah Sistem Operasi berjalan, dan Sistem Operasi akan melakukan layanan inti umum untuk software-software itu. Layanan inti umum tersebut seperti akses ke disk, manajemen memori, skeduling task, dan antar-muka user. Sehingga masing-masing software tidak perlu lagi melakukan tugas-tugas inti umum tersebut, karena dapat dilayani dan dilakukan oleh Sistem Operasi. Bagian kode yang melakukan tugas-tugas inti dan umum tersebut dinamakan dengan "kernel” suatu Sistem Operasi.

Kalau sistem komputer terbagi dalam lapisan-lapisan, maka Sistem Operasi adalah penghubung antara lapisan hardware dan lapisan software. Lebih jauh daripada itu, Sistem Operasi melakukan semua tugas-tugas penting dalam komputer, dan menjamin aplikasi-aplikasi yang berbeda dapat berjalan secara bersamaan dengan lancar. Sistem Operasi menjamin aplikasi software lainnya dapat menggunakan memori, melakukan input dan output terhadap peralatan lain dan memiliki akses kepada sistem file. Apabila beberapa aplikasi berjalan secara bersamaan, maka Sistem Operasi mengatur skedule yang tepat, sehingga sedapat 
mungkin semua proses yang berjalan mendapatkan waktu yang cukup untuk menggunakan prosesor (CPU) serta tidak saling mengganggu.

\section{F.Mesin Virtual}

Mesin virtual pada mulanya didefinisikan oleh Gerard J. Popek dan Robert P.

Goldberg pada tahun $\underline{1974}$ sebagai sebuah duplikat yang efisien dan terisolasi dari suatu mesin asli. Pada masa sekarang ini, mesin-mesin virtual dapat mensimulasikan perangkat keras walaupun tidak ada perangkat keras aslinya sama sekali. $\stackrel{[1]}{[}$

Contohnya adalah program yang ditulis dalam bahasa Java akan dilayani oleh Java Virtual Machine (JVM) dengan cara memberikan perintah-perintah yang dimengerti JVM yang selanjutnya akan memberikan hasil yang diharapkan. Dengan memberikan layanan seperti ini kepada program tersebut, perangkat lunak JVM ini berlaku sebagai sebuah "mesin virtual", sehingga program tidak lagi perlu untuk mengakses langsung melalui sistem operasi ataupun perangkat keras yang sangat bervariasi dan memerlukan pemrograman masing-masing secara spesifik.

Mesin virtual terdiri dari dua kategori besar, dipisahkan menurut cara penggunaan dan tingkat keterhubungannya dengan mesin-mesin aslinya. Sebuah mesin virtual sistem adalah perangkat yang berupa platform sistem yang lengkap dan dapat

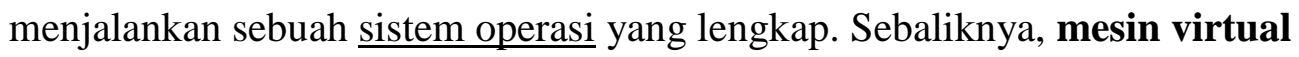
proses didesain untuk menjalankan sebuah program komputer tertentu (tunggal), yang berarti mesin virtual ini mendukung proses tertentu juga. Karakteristik mendasar dari sebuah mesin virtual adalah batasan-batasan bagi perangkat lunak yang berjalan di dalam mesin tersebut, sumber daya yang dibatasi, dan tidak dapat mengakses ke luar tembok batasan dunia maya itu. 


\section{A. ID SECURITY}

QWTD44112377-ASP-524414475

\section{B. REFERENCE}

[1] O. M. Febriani and A. S. Putra, "Sistem Informasi Monitoring Inventori Barang Pada Balai Riset Standardisasi Industri Bandar Lampung," J. Inform., vol. 13, no. 1, pp. 90-98, 2014.

[2] A. S. Putra, "Paperplain: Execution Fundamental Create Application With Borland Delphi 7.0 University Of Mitra Indonesia," 2018.

[3] A. S. Putra, "2018 Artikel Struktur Data, Audit Dan Jaringan Komputer," 2018.

[4] A. S. Putra, "ALIAS MANAGER USED IN DATABASE DESKTOP STUDI CASE DB DEMOS."

[5] A. S. Putra, "COMPREHENSIVE SET OF PROFESSIONAL FOR DISTRIBUTE COMPUTING."

[6] A. S. Putra, "DATA ORIENTED RECOGNITION IN BORLAND DELPHI 7.0."

[7] A. S. Putra, "EMBARCADERO DELPHI XE 2 IN GPU-POWERED FIREMONKEY APPLICATION."

[8] A. S. Putra, "HAK ATAS KEKAYAAN INTELEKTUAL DALAM DUNIA TEKNOLOGY BERBASIS REVOLUSI INDUSTRI 4.0."

[9] A. S. Putra, "IMPLEMENTASI PERATURAN PERUNDANGAN UU. NO 31 TAHUN 2000 TENTANG DESAIN INDUSTRI BERBASIS INFORMATION TECHNOLOGY."

[10] A. S. Putra, "IMPLEMENTATION OF PARADOX DBASE."

[11] A. S. Putra, "IMPLEMENTATION OF TRADE SECRET CASE STUDY SAMSUNG MOBILE PHONE."

[12] A. S. Putra, "IMPLEMENTATION PATENT FOR APPLICATION WEB BASED CASE STUDI WWW. PUBLIKLAMPUNG. COM."

[13] A. S. Putra, "IMPLEMENTATION SYSTEM FIRST TO INVENT IN DIGITALLY INDUSTRY."

[14] A. S. Putra, "MANUAL REPORT \& INTEGRATED DEVELOPMENT ENVIRONMENT BORLAND DELPHI 7.0."

[15] A. S. Putra, "PATENT AS RELEVAN SUPPORT RESEARCH."

[16] A. S. Putra, "PATENT FOR RESEARCH STUDY CASE OF APPLE. Inc."

[17] A. S. Putra, "PATENT PROTECTION FOR APPLICATION INVENT."

[18] A. S. Putra, "QUICK REPORT IN PROPERTY PROGRAMMING."

[19] A. S. Putra, "REVIEW CIRCUIT LAYOUT COMPONENT REQUIREMENT ON ASUS NOTEBOOK."

[20] A. S. Putra, "REVIEW TRADEMARK PATENT FOR INDUSTRIAL TECHNOLOGY BASED 4.0." 
[21] A. S. Putra, "TOOLBAR COMPONENT PALLETTE IN OBJECT ORIENTED PROGRAMMING."

[22] A. S. Putra, "WORKING DIRECTORY SET FOR PARADOX 7."

[23] A. S. Putra, "ZQUERY CONNECTION IMPLEMENTED PROGRAMMING STUDI CASE PT. BANK BCA Tbk."

[24] A. S. Putra, D. R. Aryanti, and I. Hartati, "Metode SAW (Simple Additive Weighting) sebagai Sistem Pendukung Keputusan Guru Berprestasi (Studi Kasus: SMK Global Surya)," in Prosiding Seminar Nasional Darmajaya, 2018, vol. 1, no. 1, pp. 85-97.

[25] A. S. Putra and O. M. Febriani, "Knowledge Management Online Application in PDAM Lampung Province," in Prosiding International conference on Information Technology and Business (ICITB), 2018, pp. 181-187.

[26] A. S. Putra, O. M. Febriani, and B. Bachry, "Implementasi Genetic Fuzzy System Untuk Mengidentifikasi Hasil Curian Kendaraan Bermotor Di Polda Lampung," SIMADA (Jurnal Sist. Inf. dan Manaj. Basis Data), vol. 1, no. 1, pp. 21-30, 2018.

[27] A. S. Putra, H. Sukri, and K. Zuhri, "Sistem Monitoring Realtime Jaringan Irigasi Desa (JIDES) Dengan Konsep Jaringan Sensor Nirkabel," IJEIS (Indonesian J. Electron. Instrum. Syst., vol. 8, no. 2, pp. 221-232.

[28] D. P. Sari, O. M. Febriani, and A. S. Putra, "Perancangan Sistem Informasi SDM Berprestasi pada SD Global Surya," in Prosiding Seminar Nasional Darmajaya, 2018, vol. 1, no. 1, pp. 289-294. 